\title{
The Construction of the Meaning of Cafe for Millennials (Phenomenology in the Construction of the Meaning of Hanging Out for Millennials-Café User around Campus)
}

\section{${\text { Musfialdy }{ }^{*} \text {, Rika Lusrivirga }}^{2}$}

${ }^{1}$ State Islamic University of Sultan Syarif Kasim Riau, Indonesia

${ }^{2}$ State Islamic University of Sunan Kalijaga Yokyakarta, Indonesia

*Musfialdy@uin-suska-ac.id

\begin{tabular}{l}
\hline Article Info \\
\hline Received : 2021-01-16 \\
Accepted : 2021-02-10 \\
Published : 2021-03-05
\end{tabular}

Key words: café, millenial, phenomenology, nongki

Abstract
Cafes are places where people drink coffee or other drinks that don't
contain alkhohol. The purpose of this study is about cafe users on
students born between 1981-1999 (y generation or millennial
generation). Analyzing the meaning of cafes symbols on the
millennial around campus. The theory used is theoretical
phenomenon, where reality is constructed according to the
perspective of the individual who is research informant. Another
theory is the theory of social construction of reality that social
processes through action and interaction, the individual creates a
continuous, subjective, shared reality. The study is using qualitative
methodologies with with a phenomenological method. The study
informants were students of the communication program study s-2
class 2019 postgraduate programs, Faculty of Communication
Sciences, Padjadjaran University. Data gathering techniques through
observation, interviews, secondary data sources. Research facility
around the unpad campus, Jatinangor, West Java. This research
shows the meaning in cafes obtained the word "nongki" to deduce
student activities. The meaning of "nongki" means the cafe not only
the places to eat and drink but also a place to hangouts of all the
activities the students.

\section{INTRODUCTION}

The weather was cold on Thursday night, October, 10 2019. All the tables in Upnormal Café at the corner of Jatos Mall in Jatinangor, Sumedang District, were filled of college students with their respective activities. The café, which is located close to several campuses, is filled of college students most days. Based on that night observation, there were two college students, a boy and a girl on the first table. Their outfits were casual. They ordered food and soft drinks then were busy chatting. It looked like they were discussing campus assignments, as they put several things like papers and pens on the table. On the second table, there were two college girls wearing casual outfits. They have finished dining and were seriously doing some works with their laptop. On the third table, there were a college boy that looked busy with his lapotop; beside him were other college students, a boy and a girl chatting to each other. They were also wearing casual outfits.

The fourth table also filled with college students, eight girls and two boys with some food and two laptops that were on in front of them. All of them were wearing casual outfits. They gathered together in one table, but the communication pattern in this group was divided into two groups. One group were discussing particular topic while typing on the laptop, and the other group were discussing a different topic. Some groups of college students at other tables seemed to do the same activity as the group at the fourth table.

Dozens of tables in this café were occupied with college students that seemed busy with their respective activities as if they didn't care about other people's activities around them. 
Discussion and chat at several tables went lively and relaxed with jokes, teasing and laughing out loud. Students at some other tables didn't seem disturbed by the noises, they kept busy and focused with their own activities like working on laptop or with their stationeries.

Our observation was carried up to 20:00 o'clock and there were still many college students in the café. We also found that their fashion styles were casual and their language style were using informal language with slang words mixed with Sundanese daily language. Although there were foods and drinks on their tables, yet eating and drinking were not their prominent activity in the café. They spend relatively little time eating and drinking. There were other activities that consumed their time for few hours at the café. This phenomenon is interesting to be studied

Cafe is known as a place where people having coffee or other non-alcoholic beverages. The term Café comes from French vocabulary which literally means coffee. Café then developed into a place to enjoy not only coffee, but also other soft drinks and low alcoholic beverages. Café also defined as a place for people to relax and having casual conversation while enjoying food and beverages. Café is type of restaurant which prioritizing a relaxed atmosphere, entertainment and convenience of its visitors. Therefore, most café provide comfortable seating and music.

This research emphasizes on college students as a café users. The research objects are college students that were born in the year of 1981 - 1999 which is called Generation Y or millennial generation. In her scientific oration on the anniversary of the University of Padjadjaran Faculty of Communication on September 18, 2019, DR. Jenny Ratna Suminar, M.Si described the four generations that still exist today. They are Baby Boomer Generation; Generation X; Generation Y (Millenial); and Generation Z. Baby Boomer is the generation who were born between 1946 and 1965. Generation X is the generation who were born between 1966 and 1980. Generation Y (Millennial) is the generation who were born between 1981 and 1999. And Generation $\mathrm{Z}$ is the generation who were born after 2000.

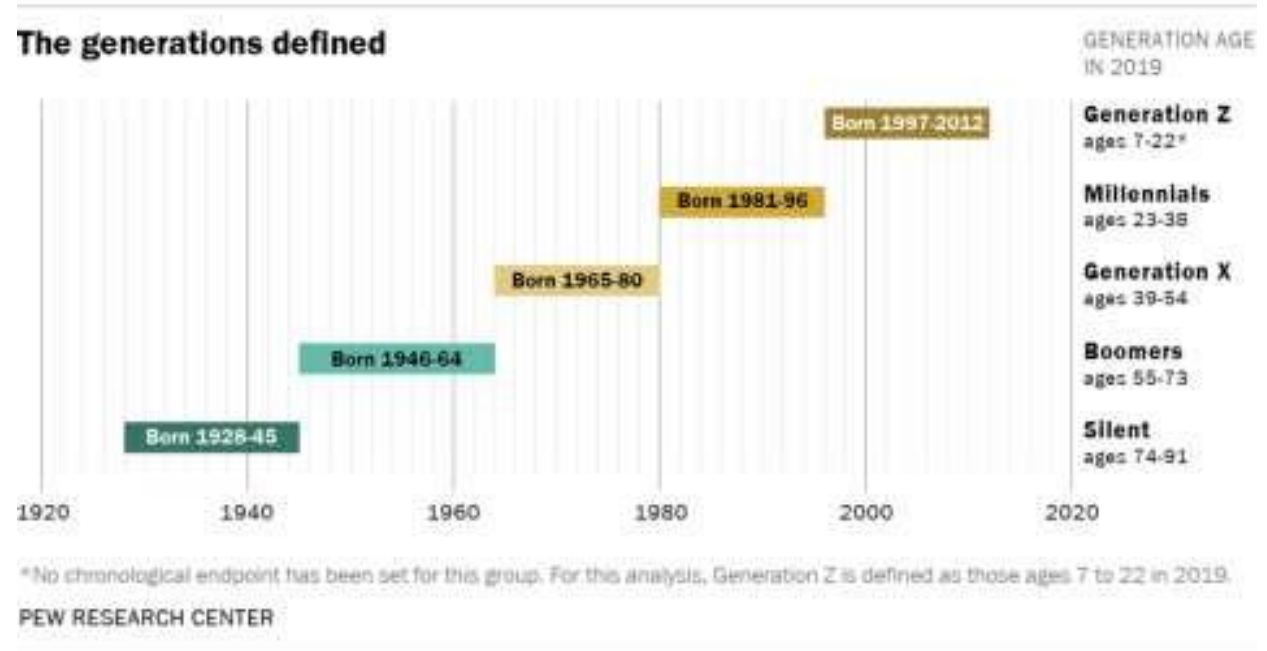

Picture: "Defining generations: Where Millennials end and Generation Z begins" (Dimock, 2018)

One of the studies about generational differences shows that the Baby Boomer, Generation X, and Generation Y (Millenial) have significant differences. Baby Boomer is defined as a generation which often too idealistic and believes in the opportunities of change, especially by entering the existing system. This generation is hard worker, highly optimistic, and wanting for personal appreciation. Generation $\mathrm{X}$ is defined as a generation who has awareness of self potency, so this generation tends to have a closed personality; very independent; and reluctant to depend on others. At the working environment, Generation $\mathrm{X}$ is 
aware of diversity; globalization; like to use practical approaches; and interested in new technologies to simplify their works. Generation $\mathrm{Y}$ is said to be a generation who greatly appreciate diversity. They prefer collaborating than taking order. They have very pragmatic view in solving problems. This generation is optimist, confident, achievement oriented, and highly open to changes and diversity (Lancaster \& Stillman, 2002; Oh \& Reeves, 2014).

In addition to college students from millennial generation, the object of this research also includes college students who often visit café, or those who visit cafe at least once a week to do certain activities. The duration of their activities is 1-2 hours or more. The informan of this research is a second year Master student of Commmunication Science at University of Padjadjaran.

\section{LITERATURE REVIEW}

Fanani, Muhamad Zainul and Haripradianto, Tito (2018) showed that Store atmosphere affects visitor behavior by $64.5 \%$ and the rest is influenced by other factors. Fauzi Ahmad, I Nengah Punia, and Gede Kamajaya (2017) described that young people often associate the rise of cafes as a part of lifestyle. Functionally, café is not only a place for enjoying coffee or hanging out, but has undergone a shift in uses values to sign values. Herlyana, Elly (2014) showed that the phenomenon of coffee shops as a part of young people's life style are drove by many psychological and social factors. Fauzi, Rizal (2018) delivered some findings of his research at Loodst Coffe Tulungagung. First, the café atsmosphere partially has a significant effect on the consumer loyalty. Second, the product quality also partially has a significant effect on the consumer loyalty. Third, the café tsmosphere, product quality, and price simultaneously have a significant effect on the consumer loyalty. Anwari, Syah Ryan (2018) described the coffee consumption behavior among college students based on Abraham Maslow's Theory of Needs.

Anwari described three values that affect the coffee consumption behavior among college students, which are friends invitation; influence of families who also a coffee drinker; and the student's financial condition. Ridho'i, Amy Manap (2017) showed that café with music is visited by young people, especially school and college students. In their research at Cabana Manado Café and Resto. Runtunuwu, Johanes Gerardo, Oroh Sem and Taroreh Rita (2014) found that, first, the product quality; price; and service quality simultaneously have a significant effect on the consumer satisfaction. Second, the product quality partially has a significant effect on the consumer satisfaction. Third, the price partially has a significant effect on the consumer satisfaction. Fourth, the service quality partially has a significant effect on the consumer satisfaction. In her research of contemporary café in Surabaya City, Hidayahtullah, Nur Abriani (2017) showed that, first, there are social constructions of college students towards contemporary café. Second, the social constructions of college students towards contemporary café are quite varied based on students' social background. Third, the current students' consumption is no longer in the essence of the food they want to eat, but in the place they want to visit. Wardhana, Aditya (2016) also showed that, first, the social constructions of college students towards contemporary café in Surabaya City started from the emergence of cafes in recent years. Second, the social constructions of college students towards contemporary café are quite varied based on students' social background. Third, the current students' consumption is no longer in the essence of the food they want to eat, but in the place they want to visit.

The originality of this research is a study on motives of the groups of millennial student towards the existence of cafes around campus. The problem formulation of this research focuses on How Millennials Interpert the Symbol of Café around the Campus? While research identification derives some questions which are: What are the motives of millennial groups in using café? and How do millennials identify themselves using those symbols? 


\section{Theoretical Frameworks}

This research is framed by three paradigms. The first is Phenomenology Theory which belongs to subjective theory group. This theory focuses on individual conscious experiences. Therefore, the reality is constructed according the perspective of individual or informant in the research. The researchers act as an instrument and not making any assumption of their informant. The researchers' role is analizying and compiling the informant's experiences, then discovering the reality based on the informan't perspective (Bajari 2015).

According to Polkinghorne (1998) in Creswell (1998:51), a phenomenology research reveals the individuals' experience about concepts or phenomena. The research is conducted in natural situation, so there is no limit in interpreting the phenomenon. Therefore, in interpreting, we must hold the principle that research actually only finds reality, not proving it. The key in finding the truth lies on the informant that being observed (Bajari 2009:75).

The second is the Constructivism Paradigm. Ritzer (1992:5) explains that the basic idea of all theories in social definition is actually view humans as a creative actor of their social reality. Humans have the freedom in many ways to act outside the control of their social structure and institution. Humans have actively and creatively develop themselves through responding the stimulus in cognitive world. In the social process, humans are viewed as the free creator of social reality in their social world.

Ontologically, the Costructivist Paradigm explains that reality is social construction created by individual. However, the truth of social reality is relative, depends on the specific context which is considered relevant by behavior (Hidayat, 1999:39).

Costructivist Paradigm views the reality as the result of creative human creation through the strength of social construction of social world around them, as Georg Simmel states that the reality of social world stands alone outside of the individual, while individual interpret it as the reality exists within oneself and its law dominates them (Veeger 1993:91).

The third is Social Contruction of Reality, which is introduced by Berger and Luckman in their book The Social Contruction of Reality: A treatise in the Sociological of Knowladge (1966). They state that the social process runs through acting and interaction, as individuals continuously create the reality that is shared and experienced together subjectively.

Furthermore, Berger and Luckman (1990:1) explain the social reality by separating the understanding of "reality" and "knowledge". Reality is defined as the quality of realities and its existence doesn't depend on one's own will. While Knowledge is defined as the certainty that realities are real and have specific characteristics.

\section{Conceptual Frameworks}

This research uses several concepts. The first is Communication Science. Communication is a systemic process where people interact through symbols to create and interpret meanings (Julia T Wood 2013). The second is Communication Symbols, as communication also emphasizes on the role and symbol that include language, non-verbal communication, music, and culture. The third is Meanings. Meanings is the heart of communication, it's a significance given to the reality / phenomenon (what is shown to us). The fourth is the Meaning of Café. Terminologically, the word café comes from French language "coffee", which means coffee (Oldenburg, 1989: 126). In Indonesia, the word café is adopted into "kafe" (Herlyana, 2012). Literally, it refers to coffee drink, then it better known as a place to enjoy coffee and various soft drinks and snacks, as defined by S. Medlik (1996: 30), "Café is establishment providing food and refreshment for consumption and the premises to general public". Furthermore, Hornby (2005) defines café in two terms, which are "a place where you can buy drink and simple meals"; and "small shop (store that sells sweets, food, newspaper, etc) usually stay open later than other shop or store". According to those definitions, café has the characteristic as a comfortable place to enjoy foods and beverages in pleasant atmosphere for gathering. 


\section{RESEARCH METHOD}

This research uses Key Informants and Informants. The key Informants of this research are an employee of Starbuck Café who is also a Master student at the Faculty of Communication Science in University of Padjadjaran; others are second year Master students at University of Padjadjaran. While the Informants are the students of Islamic State University Sunan Kalijaga, Yogyakarta and the students of Islamic State University Sultan Syarif Kasim, Riau. The Informants' criteria are those who do their activities in the café for 1-2 hours or more.

The data collection technique used in this research is Observation and Interview. Observation is a sistematically sighting and recording of the observed phenomena. Interview is a process of interaction and communication between the researchers; informants; and secondary source of data.

There are several stages in conducting the research. The first stage is Pre Field which covers preparation of research plan; determining the research field; research field's survey and assessment; preparation of research tools; and understanding of research ethics.

The second stage is Field Work which covers understanding of research's background and self preparation; and entering the research field and collecting data.

The third stage is Data Analysis which covers the activities of basic concept of data analysis arrangement; synchronization of theme and problem formulation; and determining the analytical steps to reveal the construction of meaning of symbolic communication of café user for the millennials around campus.

The fourth stage is Data Analysis Technique, which covers several steps of activity. The first is data categorization and reduction i.e collecting important informations related to the research's problem; and grouping the data according to the problem topic. The second step is arranging the data group into naratives form so it becomes a series of meaningful information in accordance with the research problem. The third is data interpretation, which interpret what has been interpreted by the informant about the observed problem. The fourth step is decision making based on the naratives that has been compiled in the third step. The fifth step is making verification of the analysis result with the informant which is based on the conclusion in the fourth step.

The fifth stage is Data Validity Checking Technique. Yin (2003) states there are four criteria of validity needed in qualitative research, i.e Construction Validity; Internal Validity; External Validity; and Reability.

The sixth stage is Researcher Role. According to Meleong (2002:121), as the research instrument, the researcher roles are being responsive in interacting with the research subjects; being adaptive and integrative to the research. The researchers should utilize their imagination and creativity; perceive the world as wholeness; and having orientation towards the development of knowledge. The researchers should be able to process the data as soon as possible and rearrange them afterward, as well as to classify and utilize the data. The researchers should have the ability to explore unsual responses; and idiosyncratic, unexpected or unusual information.

The seventh stage is the Research's Time and Schedule. This research is conducted in the area of Jatinangor, District of Sumedang, West Java Province. The area is an educational area which several leading universities are located. The research is conducted on odd semester of 2019-2020 academic years, specifically on October - November 2019.

\section{DISCUSSION}

In this part, the researchers will describe the result of the research that has been conducted in the field for two months. The researchers have observed the millennials motives in several cafes located around campus in the area of Jatinangor, Sumedang, West Java; Garuda Sakti Panam, Pekanbaru; and Yogyakarta 
There has been a shift in the meaning of café from eating place to several other meanings. This phenomenon is driven by the needs of college students in finding a place to gather and do certain activity. Those needs are accommodated by several cafes to attract customers from college students' circle.

Several cafes transformed their place, food, and service to fulfill those needs. Therefore, many cafes around campus stand with the concepts that follow the college students' taste. Besides providing varied and tasty food, they also provide excellent service and affordable price. Many cafes also renovate their places with concepts that meet the needs and convenience of college students in doing their activities at the café.

The result of interview with the informants showed several underlying motives in using café, which are:

The first is passing the time. The common motive for millenials to hang out in café is just to spend their time. They have several reasons for spending time at the café, such as a long lag time in their lecture schedule, so they would go to cafes to spend that vacant time. The timepassing activity is carried together with some friends by chatting or gossiping, playing with smartphones or doing something with their laptops. Others may use café as a transit place while waiting their classes begin, as their residence is quite far from campus. This commonly happens when they have afternoon class while they already come since morning. They would wait at the café enjoying snacks and coffee. Millennials also frequently spend time at café when they feel bored in their boarding house.

The second is companionship. Café is often used as a place to watch sport matches show together. Some millenials groups are fans to certain idols (football club, selebrity, etc), they feel they have become a part of those community. When their idols perform oversea, they would watch the show (through television channel) in certain places or cafes, together with their friends who belong to the same community or fans club. Some cafes even make their places as the base camp of those communities. Many members or fans of the community gather at café to share story and excitement. There are also many cafes with visitors who have certain uniform as their community identity.

The third is to escape. Millennials often used cafe as a place to escape from heavy assignments, problems, and pressures they had in campus. The academic or non-academic problems in campus often make some college students stressed or depressed. At those conditions, they would try to find ways to reduce the burden in their mind, one of it is come to café alone or with friends. They try to reduce stress by hanging out with friends or being alone while doing something with their smartphone or laptop at the café. Mostly, this activity is carried out on holidays such as Saturday and Sunday.

The fourt is enjoyment. Other motive for coming to a café is to enjoy the foods and beverages. Some cafes give delicious sensation of eating that attracts college students to visit their places. Some college students said that the type, variation, pleasure and price of the food that one's café served have attracted them to come. Certain foods enthusiasts are often become loyal customers who always come to enjoy the food. Furthermore, café provide a pleasant place and athmosphere so college students are comfortable to be there. They describe that being at the café can make them feel relax after a whole day studying at the campus. Some cafes are even designed with the athmosphere as relaxed as possible, so visitors feel comfortable spending a long time there

The fifth is doing homework. Working on homework becomes another motive for college students in using café. Many college students like to discuss and do their group assignment at their favorite café. They also often do their individual assignment together at the café. The result of the observation in several cafes showed there were groups of college student working on their individual assigmnents together on the same table. Athough they come together and sat on the same table, each of them was busy working on their laptops without any communication to each other. 
The sixth is information. Some college students use café as a place for sharing information with friends and seniors, whether the information about campus or other information that is not related to the campus. Informations about latest technology, lifestyle, friends, lecturers, academics, etc can be obtained from chatter at the café. Sometimes, the teaching and learning activities are not carried out in campus, but in cafes. College students consider café as a place which accommodate the latest information from friends.

The seventh is excitement. Some activities that cherish the excitement such as birthday party, graduation celebration, and other excitement are often held at cafes with friends. Those celebrations could be well planned and held formally, or held spontaneously and informal. The most important thing is they can celebrate the excitement together.

\section{RESULT AND CONCLUSION}

Based on the observation of the Phenomenology Research on the Construction of Meanings of "Hanging Out" for Millennials-Café User around Campus, the conclusion obtained are:

Firstly, it is concluded that the construction of meanings of café for Millennials are seen as café is no longer used as a place for eating and drinking, the meanings of café has widened into a place for hanging out with varied activities of their needs. The activities of eating and drinking are no longer their primary priority, but have become their secondary priority in accordance with their activities at the café. Café has become the means of education; socialization; and information for students that represent today's Millenials.

Secondly, the development of cafes around campus has undergone significant changes. The café entrepreneurs have done transformations to accommodate the needs and will of college students. The development is not only implemented on the food and beverage, but also on the quality of place, service, and price to accommodate their consumers' activity. Those efforts are ways to attract as many consumers as possible, and to make the customers feel comfortable doing their activity at the cafe for as long as possible.

From the Phenomenological Research of the meanings of café, the term of "Hanging Out" is obtained to conclude the college students' activity. "Hanging Out" means cafes are not only a place to eat and drink, but also a place to hang out or gather for doing their certain activities. The activity of eating and drinking are just a supporting factor of their motives in using café.

\section{REFERENCES}

Anwari, Syah Ryan (2018), Perilaku Konsumsi Kopi Di Kalangan Mahasiswa Di Kafe Sepanjang Jalan Kalpataru Kota Malang, Skripsi, Repository Universitas Brawijaya Malang

Bajari, Atwar. (2015). Metode Penelitian Komunikasi - Prosedur, Tren, dan Etika. Bandung: Simbiosa Rekatama Media.

Berger, Peter dan Thomas Luckmann. (2012). Tafsir Sosial Atas Kenyataan: Risalah tentang Sosiologi Pengetahuan. Jakarta: LP3ES Indonesia.

Creswell, John. W. (1998) Qualitative Inquiry and Research Design, Choosing Among Five Traditions. California: Sage Publication. H

Fanani, Muhamad Zainul, Haripradianto, Tito (2018) Pengaruh Store Atmosphere Terhadap Perilaku Pengunjung Pada Kafe La Aquanos Malang, Jurnal Mahasiswa Jurusan Arsitektur Vol 6 No 3 Page 1-9 2018 Universitas Brawijaya, Malang

Fauzi Ahmad, Punia I Nengah, Kamajaya Gede, (2017) Budaya Nongkrong Anak Muda Di Kafe (Tinjauan Gaya Hidup Anak Muda Di Kota Denpasar), Jurnal Ilmiah Sosiologi (Sorot) Vol 1 No 1 Page 1-11 Denpasar 
Fauzzi, Rizzal (2018) Pengaruh Atmosphere Café, Kualitas Produk, Dan Harga Terhadap Loyalitas Pelanggan Pada Loodst Coffe Tulunggagung, Skripsi, Repository Universitas Nusantara PGRI Kediri

Herlyana, Elly (2014), Fenomena Coffee Shop Sebagai Gejala Gaya Hidup Baru Kaum Muda Thaqãfiyyãt Vol 13 No 1 Page 187-204 Yokyakarta

Hidayahtullah Nur Abriani (2017), Realitas Kafe Kekinian Bagi Kalangan Mahasiswa Pada Komunitas Instameet Surabaya, Skripsi Repository Universitas Airlangga, Surabaya

Hornby, A S. (2005). Oxford Advance Learner's Dictionary of Current English 7 th Edition. London: Oxford University Press

Suminar, J. R. , Orasi Ilmiah pada Dies Natalis Fakultas Ilmu Komunikasi Universitas Padjadjaran tanggal 18 September 2019

Wood. Julia T (2013). Komunikasi Teori dan Praktik, (komunikasi dalam kehidupan Kita). Jakarta, Salemba

K.Yin, Robert. (2002). Studi Kasus Desain dan Metode. Jakarta: Rajawali Press.

Lancaster, L. C., \& Stillman, D. (2002). When generations collide: traditionalists, baby boomers, generation xers, millennials : who they are, why they clash, how to solve the generational puzzle at work. New York: HarperBusiness.

Medlik, S. (1996). Dictionary of Travel, Tourism and Hopitality. UK: Butterworth- Heinemann

Moleong, Lexy J. (2002). Metodologi Penelitian Kualitatif. Bandung: PT Remaja Rosdakarya.

Oh, E., \& Reeves, T. C. (2014). Generational differences and the integration of technology in learning, instruction, and performance. In Handbook of Research on Educational Communications and Technology: Fourth Edition. Springer New York.

Oldenburg, Ray. (1989). The Great Good Place: Cafes, Coffee Shops, Bookstores, Bars, Hair Salons, and other Hangouts at The Heart of a Community. London: Da Capo Press

Berger, Peter L and Thomas Luckman (1966), The Social Contruction of Reality: A treatise in the Sociological of Knowladge.

Ridho’i, Amy Manap (2017), Fenomena Musik Kafe Pada Coffeeccino Café Di Kota Pontianak, Jurnal Pendidikan dan Pembelajaran Khatulistiwa Vol 6 No 6 Page 1-12 Universitas Tanjungpura, Pontianak

Ritzer, george (1992). Sosialogi Ilmu Pengetahuan Berparadigma Ganda, Jakarta, Rajawali Pres

Runtunuwu, Johanes Gerardo, Oroh Sem, and Taroreh Rita (2014) Pengaruh Kualitas Produk, Harga, Dan Kualitas Pelayanan Terhadap Kepuasan Pengguna Cafe Dan Resto Cabana Manado, Jurnal EMBA Vol. 2 No. 3 Page 1803-1813 Manado

Wardhana, Aditya (2016), Pengaruh Store Atmosphere Terhadap Minat Beli Konsumen Pada Caffe Bene Bandung, Skripsi, Repository Telkom University Bandung. 